\title{
Radiation techniques for acromegaly
}

\author{
Giuseppe Minniti ${ }^{1,2^{*}}$, Claudia Scaringi ${ }^{2}$ and Riccardo Maurizi Enrici ${ }^{2}$
}

\begin{abstract}
Radiotherapy (RT) remains an effective treatment in patients with acromegaly refractory to medical and/or surgical interventions, with durable tumor control and biochemical remission; however, there are still concerns about delayed biochemical effect and potential late toxicity of radiation treatment, especially high rates of hypopituitarism. Stereotactic radiotherapy has been developed as a more accurate technique of irradiation with more precise tumour localization and consequently a reduction in the volume of normal tissue, particularly the brain, irradiated to high radiation doses. Radiation can be delivered in a single fraction by stereotactic radiosurgery (SRS) or as fractionated stereotactic radiotherapy (FSRT) in which smaller doses are delivered over 5-6 weeks in 2530 treatments. A review of the recent literature suggests that pituitary irradiation is an effective treatment for acromegaly. Stereotactic techniques for $\mathrm{GH}$-secreting pituitary tumors are discussed with the aim to define the efficacy and potential adverse effects of each of these techniques.
\end{abstract}

Keywords: acromegaly, fractionated stereotactic radiotherapy, radiosurgery, toxicity, GH-secreting pituitary tumors

\section{Introduction}

Acromegaly is a disorder caused by a pituitary GHsecreting adenoma and characterized by high circulating levels of GH and IGF-I. It is associated with increased morbidity and mortality rates, especially due to respiratory, cardiovascular disease, and malignant diseases [1]. Surgery, medical therapy, and radiotherapy (RT) are the available treatments employed with the aim of normalizing GH and IGF-I hypersecretion, controlling pituitary tumor mass effects, preventing recurrences, and improving morbidity. Transsphenoidal surgery is the procedure of choice for the initial management of acromegaly, leading to the remission of disease in $42-65 \%$ of patients [2], and achieving a rapid improvement of metabolic and cardiovascular abnormalities [3,4]. Medical therapy, mainly with long-acting somatostatin analogs, permits a normalization of GH/IGF-I hypersecretion in up to 70\% of cases with an apparently low incidence of side effects [5]. RT is currently proposed to a subset of patients with persistent active disease after surgery and/or during medical therapy. In most of published studies conventional RT achieves tumor growth control in $85-95 \%$ of cases, dropping out GH/IGF-I levels to less than $5 \mathrm{ng} /$ $\mathrm{ml}$ in up to $80 \%$ of patients $10-15$ years after RT [6].

\footnotetext{
* Correspondence: gminniti@ospedalesantandrea.it

'Department of Neuroscience, Neuromed Institute, Pozzilli (IS), Italy

Full list of author information is available at the end of the article
}

Despite its efficacy, there are concerns about the necessity and potential toxicity of RT and its use remains matter of debate.

More recently, stereotactic radiation techniques have been employed in patients with acromegaly with the aim of treating less normal brain and of minimizing the long-term consequences of RT while improving its effectiveness [7]. Stereotactic radiotherapy can be given as a single treatment (stereotactic radiosurgery-SRS) using either cobalt-60 gamma radiation-emitting sources (Gamma-Knife) or linear accelerator (LINAC), or as fractionated stereotactic radiotherapy (FSRT). Although stereotactic techniques have the clear advantage to offer a more precise radiation delivery compared with conventional $\mathrm{RT}$, the question regarding their superiority and efficacy in the management of patients with acromegaly remains to be demonstrated.

In this review, we present a critical analysis of the more recent available literature in the management of patients with acromegaly, in an attempt to define reasonably objective and comparative information on the safety and efficacy of the individual techniques.

\section{Fractionated Radiotherapy}

Modern RT even without the recourse to stereotactic techniques has seen advances in all aspects of treatment with better immobilization, imaging, planning and treatment. Patients are typically immobilized in a custom
C Biomed Central 
made plastic mask with movement limited to $2-5 \mathrm{~mm}$. Tumour localization, initially based on plain X-ray visualization of the pituitary fossa, has improved with the routine use of fused CT/MRI imaging. A margin of $3-10 \mathrm{~mm}$ beyond the visible extent of tumour is included in the treatment planning to allow for patient movement and set-up variation during the treatment. Three-dimensional (3D) treatment planning provides more accurate visualization of dose distribution as compared with 2D planning, with the option of giving a more homogeneous dose within the target and lower dose to the organs at risk of radiation toxicity. More precise delivery is achieved conforming the radiation beams to the shape of tumor (conformal radiotherapy) and increasing the number of beams. This results either in reduction of volume of normal brain receiving high dose of radiation or in a greater dose differential between the target and normal brain tissue. The total dose of 45-55 Gy is achieved by daily doses of 1.8-2.0 Gy, with treatment lasting for 5-6 weeks.

Published series assessing the long term effectiveness of conventional RT in patients with acromegaly report tumor control and normalization of GH/IGF-I levels in the region of $80-90 \%$ and $50-60 \%$ at 10 years, respectively. The reported results are summarized in Table 1
[8-15]. Differing from earlier series based on basal GH levels $<5-10 \mu \mathrm{g} /$ liter to evaluate the biochemical remission of acromegaly after pituitary irradiation, more stringent criteria for disease control are currently used [16].

In a series of 45 patients with active acromegaly treated with external beam RT at University of Rome La Sapienza between 1982 and 1994 survival rates were $98 \%, 95 \%$, and $93 \%$, and local tumor control rates $95 \%$ at 5,10 and 15 years after treatment [14]. Biochemical remission of disease as defined by GH levels below 1 $\mathrm{ng} / \mathrm{ml}$ during an oral glucose tolerance test (OGTT) was seen in $9 \%$ of patients at 2 years, $29 \%$ at 5 years, $52 \%$ at 10 years, and $77 \%$ at 15 years, respectively. IGF-I levels were normal in $8 \%$ of patients 2 years after RT, and this proportion increased to $23 \%, 42 \%$ and $61 \%$ after 5,10 and 15 years, respectively. In a large retrospective series of 656 patients with acromegaly treated with conventional pituitary irradiation in the United Kingdom the proportion of patients who achieved a safe GH $(<2.5$ $\mathrm{ng} / \mathrm{ml}$ ) was $22 \%$ at 2 years, $36 \%$ at 5 years, $60 \%$ at 10 years, and $74 \%$ at 15 years [15]. The biochemical remission rates were $35 \%, 49 \%, 73 \%$, and $88 \%$ at $2,5,10$, and 15 years for patients with a preirradiation GH levels less than $10 \mathrm{ng} / \mathrm{ml}$, compared with $11 \%, 27 \%, 51 \%$, and $69 \%$ for patients with preirradiation GH levels of 10-30 ng/

Table 1 Summary of results of recent series on fractionated radiotherapy for GH-secreting pituitary adenoma

\begin{tabular}{|c|c|c|c|c|c|c|c|c|}
\hline \multirow[t]{2}{*}{ Authors } & \multirow{2}{*}{$\begin{array}{l}\text { type } \\
\text { of } \\
\text { RT }\end{array}$} & \multirow[t]{2}{*}{ patients } & \multirow{2}{*}{$\begin{array}{l}\text { total } \\
\text { dose } \\
(G y)\end{array}$} & \multirow{2}{*}{$\begin{array}{c}\text { follow-up } \\
\text { median } \\
\text { (months) }\end{array}$} & \multirow{2}{*}{$\begin{array}{c}\text { tumor } \\
\text { control } \\
\%\end{array}$} & \multirow{2}{*}{$\begin{array}{c}\text { biochemical remission } \\
\%\end{array}$} & \multicolumn{2}{|c|}{ late toxicity (\%) } \\
\hline & & & & & & & visual & hypopituitarism \\
\hline Barkan et al., 1997 [8] & CRT & 38 & 46 & 80 & NA & 5 & NA & NA \\
\hline $\begin{array}{l}\text { Thalassinos et al., } 1998 \\
\text { [9] }\end{array}$ & CRT & 46 & $45-50$ & 86 & 100 & $\begin{array}{c}25 \text { and } 21 \text { at } 5 \text { and } 10 \\
\text { years }\end{array}$ & 0 & 30 at 10 years \\
\hline Barrande et al., 2000 [10] & CRT & 128 & 52 & 137 & NA & $\begin{array}{c}35 \text { and } 53 \text { at } 5 \text { and } 10 \\
\text { years }\end{array}$ & 3 & 50 at 10 years \\
\hline Biermasz et al., 2000 [11] & CRT & 36 & 40 & 130 & NA & $\begin{array}{c}40 \text { and } 61 \text { at } 5 \text { and } 10 \\
\text { years }\end{array}$ & 0 & $\begin{array}{c}29 \text { and } 54 \text { at } 5 \text { and } 10 \\
\text { years }\end{array}$ \\
\hline Cozzi et al., 2001 [12] & CRT & 49 & 45 & 168 & 96 & 10 at 10 years & 4 & 12 \\
\hline $\begin{array}{l}\text { Epaminonda et al., } 2001 \\
\text { [13] }\end{array}$ & CRT & 67 & $40-75$ & 120 & NA & 65 at 15 years & 0 & NA \\
\hline \multirow[t]{2}{*}{ Jenkins et al., 2006 [15] } & CRT & 656 & 45 & 84 & NA & $\begin{array}{c}36 \text { and } 64 \text { at } 5 \text { and } 10 \\
\text { years }\end{array}$ & 0 & 58 at 10 years $^{\circ}$ \\
\hline & & & & & & 74 at 15 years & & \\
\hline \multirow[t]{2}{*}{ Minniti et al., 2005 [14] } & CRT & 45 & 45 & 144 & 95 & $\begin{array}{c}29 \text { and } 52 \text { at } 5 \text { and } 10 \\
\text { years }\end{array}$ & 0 & 45 at 10 years \\
\hline & & & & & & 77 at 15 years & & \\
\hline $\begin{array}{l}\text { Milker-Zabel et al.,2004 } \\
\text { [26] }\end{array}$ & FSRT & 20 & 52.2 & 61 & 100 & 55 & 5 & 15 \\
\hline Colin et al., 2005 [27] & FSRT & $31^{*}$ & 50.4 & 80 & 99 & $\begin{array}{c}20 \text { and } 50 \text { at } 5 \text { and } 10 \\
\text { years }\end{array}$ & 0 & 37 \\
\hline Minniti et al., 2006 [28] & FSRT & $18^{*}$ & 45 & 39 & 98 & 50 at 5 years* & 0 & 22 \\
\hline Roug et al., 2010 [29] & FSRT & 34 & 54 & 45 & 91 & 30 & NA & 29 \\
\hline
\end{tabular}

CRT, conventional radiotherapy; FSRT, fractionated stereotactic radiotherapy.

*acromegalic patients included in series of FSRT for either secreting or non secreting pituitary tumors.

'hypogonadism $58 \%$, hypothyroidism $27 \%$, and hyposurrenalism $15 \%$, respectively. 
ml. Normalization of IGF-I was observed in $38 \%$ of patients at 2 years, $50 \%$ at 5 years, $63 \%$ at 10 years, and $56 \%$ at 15 years, respectively. Similar effects of pituitary irradiation on GH and IGF-I levels have been reported in some other retrospective series $[10,11]$.

Analysis of rate of declining of individual GH levels shows that plasma $\mathrm{GH}$ declines gradually to approximately $50 \%$ of the preirradiation value at 2 years, to $20 \%$ at 5 years, and to $10 \%$ at 10 years, with a slower decline of IGF-I concentration in the range of $50 \%-60 \%$ at 10 years $[10,11,14]$. This means that the interval to achieve biochemical remission of acromegaly mainly depends on GH/IGF-I preirradiation levels. Although RT was found effective in the majority of treated patients in most series, few studies reported a less favourable outcome $[8,9,12]$. Differences in the length of follow-up, disease activity, and biochemical testing procedures may, at least in part, be responsible for these discrepancies.

The risk of late normal central nervous system toxicity of external beam RT to doses less than 50 Gy at 2 Gy per fraction is low, with a reported incidence of optic neuropathy resulting in visual deficits of $1-5 \%$, and a risk of necrosis of normal brain structures of $0-2 \%$. Hypopituitarism represents the most commonly reported late complication of $\mathrm{RT}$, and its frequency increases with longer follow-up, occurring in up to $60 \%$ of irradiated patients 10 years after treatment (Table 1 ). An increased incidence of cerebrovascular accidents (CVA) and related mortality has been reported in patients with acromegaly treated with conventional RT $[17,18]$. Brada et al [17] found an increased mortality in a series of 334 irradiated patients with a 1.6-fold excess of CVA, and similar results have been reported by others [18]. Since other possible risk factors include GH/IGF-/excesses, hypopituitarism, and extensive surgery, a direct link between RT and cerebrovascular events remains to be proven. Conventional radiation of pituitary tumors has been associated with the development of secondary radiation-induced neoplasm, usually a glioma or a meningioma $[19,20]$. In a cohort of 426 patients with pituitary adenomas [20] who received CRT at the Royal Marsden Hospital (RMH) between 1962 and 1994, the cumulative risk of second brain tumours was $2.0 \%$ (95\% CI: $0.9-4.4 \%)$ at 10 years and $2.4 \%(95 \%$ CI: $1.2-5.0 \%)$ at 20 years. The results are in consistent with the reported cumulative risk of secondary glioma after radiation of $2.7 \%$ at 15 years in a cohort of 305 patients with pituitary adenomas [19]. Developmental problems leading to neurocognitive impairment, particularly in children, is a recognized consequence of large volume cranial irradiation [21]; however, there is little evidence that fractionated irradiation for pituitary adenomas may significantly alters cognitive function [22-24].
FSRT is a refinement of high conformal RT with further improvement in immobilization and delivery. Patients undergoing FSRT are usually immobilized in a highly precision frameless stereotactic mask fixation system with a reported accuracy of 1-2 $\mathrm{mm}$ [25], so that it is possible to administrate stereotactic irradiation in a number of small doses/fractions. Thus, the principal aim of FSRT is to deliver more localized irradiation as compared with conventional RT, leading to a reduction of the volume of normal brain tissue irradiated to high radiation doses, possibly minimizing the long-term consequences of treatment.

Only few series report on the use of FSRT in patients with $\mathrm{GH}$-secreting pituitary adenomas showing tumor control and biochemical remission rates of $90-100 \%$ and $8-55 \%$ at a variable follow-up of 30-60 months [26-29] (Table 1). In a series of 18 patients with acromegaly treated with FSRT at Royal Marsden Hospital biochemical remission was achieved in 35\% after a median follow-up of 39 months [28]. Actuarial normalization of GH/IGF-I levels was $20 \%$ at 3 years and $50 \%$ at 5 years. MilkerZabel et al. [26] reported 5-year local and hormonal control rates of $100 \%$ and $80 \%$, respectively, in 20 patients with acromegaly. At a median follow-up of 30 months Roug et al. [29] observed biochemical remission of disease, as defined by suppressed GH at OGTT and normal IGF-I levels adjusted for age, in $30 \%$ of 34 patients with active acromegaly, being 24\%, 38\% and $64 \%$ after 1,3 and 5 years, respectively. An additional $20 \%$ of patients achieved normal GH and IGF-I levels with the use of somatostatin analogs during the follow-up.

A low radiation-induced toxicity has been reported after FSRT. Hypopituitarism is the most common complication of treatment and has been reported in 15-37\% of patients at median follow-up ranging from 39 to 80 months, whereas the reported incidence of optic neuropathy is $1-5 \%$. The incidence of hypopituitarism is likely to remain the major late effect of FSRT since it does not result in a significant reduction of dose to the hypothalamus and the residual normal pituitary tissue. Although no cases of CVA and second tumors have been reported after FSRT, the incidence of the former increases with time, and secondary tumors usually occur with many years delay. Although treating less normal brain at high radiation doses may translate in a reduction of the development of such radiation induced complications, large series and longer follow-ups need to demonstrate these potential clinical advantages. Similarly, the lack of formal cognitive function testing and quality of life assessment in all published series does not allow for definitive conclusion about the potential superiority of stereotactic techniques as compared with 3D conformal RT, and this will need to be addressed in future studies. 
Intensity-modulated radiation therapy (IMRT) represents an advanced form of 3D conformal RT with the potential to achieve a much higher degree of target conformity while minimizing radiation exposure to surrounding normal tissues, especially for tumors with complex shapes and concave regions close to sensitive structures. IMRT uses a series of multiple subfields created by a multileaf collimator (MLC) which move under computer control creating modulated fields. IMRT treatment plans are generated using inverse planning system, which uses computer optimization techniques to modulate intensities across the target volume and sensitive normal structures, starting from a specified dose distribution. IMRT may result in a more conformal and better coverage than $3 \mathrm{D}$ conformal $\mathrm{RT}$ and therefore is able to spare more normal brain. In 34 patients with pituitary adenoma treated with IMRT at a median follow-up of 42 months local control was 89\% [30]. However, there are no reported clinical data on IMRT in acromegaly, and currently, it is not possible to conclude that IMRT confers any advantage over other techniques with respect to either hormonal control or toxicity.

Particle radiation has been also applied successfully in the treatment of pituitary adenomas. The physical properties of proton irradiation can offer superior conformality in dose distribution when compared to 3D conformal RT and IMRT. Distribution of low and intermediate doses to portions of the brain in children irradiated for common brain tumors are significantly lower with protons when compared with photons [31], and the advantage becomes more apparent for large volumes. Proton therapy can be delivered as SRS or as FSRT with the same immobilization systems and target accuracy of photon techniques.

Petit JH et al [32] reported on 22 patients with persistent acromegaly who were treated with single fraction proton radiosurgery at Massachusetts General Hospital. Using a median dose of 20 GyE biochemical remission was achieved in $50 \%$ of patients, with a median time to complete response of 30.5 months. One-third of patients developed at least one new pituitary deficiency, requiring medical therapy. In a small series of 11 acromegalic patients treated with fractionated proton beam irradiation at a median time of 83 months hormonal normalization occurred in $45 \%$ of patients, with an actuarial rate of $23 \%$ at 5 years [33]. Currently, no data suggest the superiority of protons in the treatment of pituitary tumors as compared with other radiation techniques.

\section{Stereotactic radiosurgery (SRS)}

SRS is given using either a multiple cobalt-60 $\left({ }^{60} \mathrm{Co}\right)$ gamma radiation-emitting sources gamma knife (GK) or a modified linear accelerator (LINAC). GK is the most widely published radiosurgical methodology used to treat pituitary adenomas. In its most common design, a total of 201 sources of ${ }^{60} \mathrm{Co}$ are arranged in a hemisphere and focused with a collimator helmet on a single or multiple fixed points (isocenters). CT localization and computerized 3D planning are used to determine the optimal number and distribution of isocenters, and this can be aided by selective occlusion of collimator apertures. During SRS, patients are usually immobilized in a fixed frame with a positioning accuracy of $<1 \mathrm{~mm}$. Similar dose distribution can be obtained with a LINAC using multiple noncoplanar arcs of rotation or multiple noncoplanar fixed beams.

SRS has been extensively employed in the last two decades in patients with residual pituitary tumors. At a median follow-up ranging between 31 and 60 months the reported tumor growth control following SRS in patients with acromegaly is between 88 and 97\% [34-48] (Table 2). A variable reduction in tumor size has been observed in $30-60 \%$ of patients after the treatment.

Biochemical remission of disease has been reported in $35-100 \%$ of patients with GH-secreting adenomas. The variable rate of control disease may reflect the different lengths of follow-up and criteria used to define the biochemical control of disease, making difficult the evaluation of the real efficacy of SRS. Nevertheless, when stringent criteria of cure as defined by suppressed GH levels during OGTT and normal age-corrected IGF-I levels are considered, the 5-year actuarial biochemical remission has been reported in $30-60 \%$ of patients following SRS, including patients who achieved normal GH/IGF-I levels during medical treatment with somatostatin analogs, and normalization of GH/IGF-I levels continues throughout the follow-up period $[36,40-42,44]$ (Table 2).

Losa et al [44] in a retrospective analysis of 83 patients with acromegaly treated with GK SRS at University of Milan San Raffaele between 1994 and 2006 have reported actuarial biochemical remission rates of $30 \%, 52 \%$ and $85 \%$ at 3,5 and 10 years, respectively. Jagannathan et al [43] observed normalization of the serum IGF-1 in $53 \%$ of 95 patients treated with GK SRS and at least 18 months of follow-up. The mean time to remission was 30 months; twelve patients achieved endocrine remission within the first year of treatment, 28 within 2 years, and 34 within 3 years, respectively. Jezkova et al [39] in a series of 96 patients reported hormonal remission rates of $45 \%$ at 3 years, $58 \%$ at 5 years, and $57 \%$ at 8 years, respectively. The median time to achieve GH suppression < $1 \mu \mathrm{g} / \mathrm{l}$ during an OGTT and normal IGF-I was 66 months. Similar biochemical remission rates in the range of $45-60 \%$ at 5 years have been shown by others $[41,42]$, although lower rates have been reported in some series $[34,36,40,48]$. There are only few studies on the efficacy of LINAC SRS for the 
Table 2 Summary of results of recent series on stereotactic radiosurgery for GH-secreting pituitary adenomas

\begin{tabular}{|c|c|c|c|c|c|c|c|c|}
\hline \multirow[t]{2}{*}{ Authors } & \multirow[t]{2}{*}{ patients } & \multirow{2}{*}{$\begin{array}{c}\text { type of } \\
\text { SRS }\end{array}$} & \multirow{2}{*}{$\begin{array}{l}\text { total } \\
\text { dose } \\
(\mathrm{Gy})\end{array}$} & \multirow{2}{*}{$\begin{array}{l}\text { follow-up } \\
\text { median } \\
\text { (months) }\end{array}$} & \multirow{2}{*}{$\begin{array}{l}\text { tumor } \\
\text { control } \\
(\%)\end{array}$} & \multirow{2}{*}{$\begin{array}{l}\text { biochemical remission } \\
\text { (\%) }\end{array}$} & \multicolumn{2}{|r|}{ late toxicity (\%) } \\
\hline & & & & & & & visual & hypopituitarism \\
\hline Attanasio et al., 2003 [34] & 30 & GK SRS & 20 & 46 & 100 & 30 at 5 years & 0 & 6.7 \\
\hline Jane et al., 2003 [35] & 64 & GK SRS & 15 & $>18$ & NA & 36 & 0 & 28 \\
\hline Castinetti et al., 2005 [36] & 82 & GK SRS & 26 & $49.5^{*}$ & NA & 17 & 1.2 & 17 \\
\hline Gutt et al., 2005 [37] & 44 & GK SRS & 23 & 22 & 100 & 48 & NA & NA \\
\hline $\begin{array}{l}\text { Kobayashi et al., } 2005 \\
\text { [38] }\end{array}$ & 67 & GK SRS & 18,9 & 63 & 100 & 17 & 11 & 15 \\
\hline Jezkova et al., 2006 [39] & 96 & GK SRS & 32 & 53.7 & 100 & 44 at 5 years & 0 & 27.1 \\
\hline Voges et al., 2006 [40] & 64 & $\begin{array}{l}\text { LINAC } \\
\text { SRS }\end{array}$ & 16,5 & 54.3 & 97 & $\begin{array}{c}14 \text { and } 33 \text { at } 3 \text { and } 5 \\
\text { years }\end{array}$ & 1.4 & $\begin{array}{c}13 \text { and } 18 \text { at } 3 \text { and } 5 \\
\text { years }\end{array}$ \\
\hline Petit et al., 2007 [32] & 22 & PSRS & 20 GyE & 75.6 & 100 & 59 & 0 & 38 \\
\hline Pollock et al., 2007 [41] & 46 & GK SRS & 20 & 63 & 100 & $\begin{array}{c}11 \text { and } 60 \text { at } 2 \text { and } 5 \\
\text { years }\end{array}$ & 0 & 33 at 5 years \\
\hline Vik-Mo et al., 2007 [42] & 53 & GK SRS & 26.5 & 67 & 100 & $\begin{array}{c}58 \text { and } 86 \text { at } 5 \text { and } 10 \\
\text { years }\end{array}$ & 3.8 & 10 at 5 years \\
\hline $\begin{array}{l}\text { Jagannathan et al., } 2008 \\
\text { [43] }\end{array}$ & 95 & GK SRS & 22 & 57 & 98 & 53 & 4 & 34 \\
\hline Losa et al., 2008 [44] & 83 & GK SRS & 21,5 & 69 & 97 & $\begin{array}{c}52 \text { and } 85 \text { at } 5 \text { and } 10 \\
\text { years }\end{array}$ & 0 & 10 at 10 years \\
\hline Ronchi et al., 2009 [45] & 35 & GK SRS & 20 & 114 & 100 & 46 at 10 years & 0 & 50 \\
\hline Wan et al., 2009 [46] & 103 & GK SRS & 21,4 & 67 & 95 & 37 & 0 & 6 \\
\hline Hayashi et al., 2010 [47] & 25 & GK SRS & 25.2 & 36 & 100 & 40 & 0 & 0 \\
\hline Iwai et al., 2010 [48] & 26 & GK SRS & 20 & 84 & 96 & $\begin{array}{c}17 \text { and } 47 \text { at } 5 \text { and } 10 \\
\text { years }\end{array}$ & 0 & 8 \\
\hline
\end{tabular}

*mean follow-up; NA not assessed.

SRS, stereotactic radiosurgery; GKS, Gamma Knife radiosurgery.

PSRS; proton stereotactic radiosurgery.

treatment of GH-secreting pituitary adenomas [40]; in general, they show comparable efficacy to GK SRS.

Several factors including preirradiation GH/IGF-I levels, the use of somatostatin analogs, and radiosurgical dose have been correlated with the endocrinological outcome after SRS, although disagreement exists across the published series.

High GH and/or IGF-I levels have been found independently associated with worse SRS outcome in some series $[36,39,41,44]$, similar to that reported after conventional RT $[10,11,14,15]$. Losa et al [44] reported a median time for remission of 37 months for patients with pre-treatment $\mathrm{GH}$ levels $\leq 7 \mu \mathrm{g} /$ liter as compared with 93 months for patients with GH levels $>7 \mu \mathrm{g} /$ liter. IGF-I levels $\leq 1.8$ times the upper limit of normal reached remission at a median time of 36 months as compared with 90 months for patients with $>1.8$ times the upper limit of normal. Similarly, in a retrospective analysis of 46 consecutive patients treated by SRS between 1991 and 2004 at Mayo Clinic, preirradiation IGF-I levels were independently correlated with biochemical remission. The 3 -year and 5 year biochemical remission rates were $40 \%$ and $90 \%$ for patients with IGF-I levels less than 2.25 times the upper limit of normal, and $23 \%$ and $38 \%$ with IGF-I levels greater than 2.25 times the upper limit of normal, respectively. Although no relationship between baseline hormonal levels and remission of acromegaly has been reported in few series [34,42], it seems reasonable that patients with near-normal GH and IGF-I levels are more likely to achieve hormonal remission than patients with markedly abnormal pretreatment levels.

Whether the concomitant use of somatostatin analogs at the time of SRS is a negative predictor of endocrine normalization remains matter of debate. In Landolt at al. [49] and Pollock et al. [41] series the use of suppressive medications at the time of SRS negatively correlated with biochemical remission of disease and increased the time to hormonal normalization. In contrast, other authors failed to show any detrimental effect of medical treatment on outcome $[34,36,44]$. Although somatostatin analogs withdrawal before SRS has gained an increase acceptance in clinical practice, future prospective studies are needed to elucidate the issue.

A variable dose of 18-32 Gy has been employed for SRS in acromegaly. With some exceptions, marginal dose to the tumor was not independently associated with higher rate of remission or faster normalization of 
hormone hypersecretion [34-48]. Currently, a marginal dose of about 20-25 Gy seems appropriate to achieve either tumor control or hormonal normalization.

The reported overall rate of serious complications after SRS is low (Table 2). The main complication is hypopituitarism which is reported in $0-47 \%$ of patients, with higher rates in those series with longer median follow-up (Table 2). Pollock et al. [41] reported that one third of 39 patients with acromegaly had a new pituitary deficit following GK SRS, with an actuarial incidence of new anterior pituitary deficits of $10 \%$ at 2 years and 33\% at 5 years, respectively. In a series of 95 patients with acromegaly treated with GK SRS new endocrine deficiencies were observed in $34 \%$ of patients. Incidence was only $5 \%$ at 12 months after SRS, however increased to more than $1 / 3$ in patients with a follow-up longer than 49 months. A similar incidence of hypopituitarism at 5 years in the region of $20-40 \%$ has been observed in few other series $[39,42,45]$, suggesting that it will likely increase significantly over time.

Other treatment-related complications occur rarely after SRS. To minimize visual complications the dose received by optic apparatus is usually restricted to less than 8-10 Gy. In clinical practice this means that a distance between tumor margin and optic apparatus should be at least of $2-3 \mathrm{~mm}$ to avoid the risk of visual deterioration while delivering an effective dose of 16-20 Gy to the tumor. Cavernous sinus is frequently irradiated at high dose in patients with residual pituitary tumor, although cranial neuropathies, brain radionecrosis, and carotid artery stenosis have been reported infrequently following SRS. Loeffler et al. [50] reported two cases of secondary brain tumors after SRS for a pituitary adenoma. The risk to develop a new tumor after SRS appears to be significantly less than that seen following fractionated RT [20], however the relatively short length of follow-up of most published series does not allow for any definitive conclusion.

CyberKnife (Accuray, Sunnyvale, CA) is a relatively new technological advancement in radiation therapy in which a miniaturized low energy linear accelerator is mounted on a robotic arm. The main advantage of Cyberknife system is that it allows for frameless imageguided radiation treatments achieving the same level of targeting precision as frame-based SRS. It can be used for multisession SRS (hypofractionated stereotactic radiotherapy) in patients with tumors involving the optic apparatus and who are not suitable for SRS [51]. Initial experiences with the application of CyberKnife SRS or hypofractionated SRT in treating patients with acromegaly are promising $[52,53]$. In a report of nine patients with acromegaly treated with CyberKnife to doses of 18-24 Gy in one to three fractions, biochemical remission was observed in 4 patients at a mean follow up of 25.4 months [53]. The efficacy of hypofractionated treatment schedules which may offer a reduced risk of radiation-related adverse effects as compared to single fraction radiosurgery needs to be evaluated in future studies.

A comparison of SRS with FSRT in terms of endocrinological outcome and toxicity is difficult to perform since the choice of the different stereotactic treatment modalities is based on different tumor characteristics: patients with large tumors in close proximity of optic apparatus are likely to be treated with FSRT than SRS. In current practice SRS is usually offered to patients with relatively small adenomas less than $3 \mathrm{~cm}$ in size and more than 2-3 $\mathrm{mm}$ away from the optic apparatus in order to avoid irradiation of the optic apparatus beyond single doses of 8-10 Gy. In contrast, there is no restriction to the size and the position of adenomas suitable for standard dose fractionated RT, since the treatment is delivered within the radiation tolerance limits of neural tissue, including the optic apparatus. Although early series reported a faster decline of serum GH concentration after GK SRS as compared with FSRT $[49,54]$, the superiority of SRS in terms of time to hormonal normalization remains to be demonstrated. Recent series have in fact showed that the rate of decline of GH/IGF-I levels observed following SRS is in the same region of that observed following fractionated $\mathrm{RT}$, suggesting that the variable time to hormonal normalization is more dependent on preirradiation $\mathrm{GH} /$ IGF-I levels than differences in radiation techniques $[34,36]$. A lower incidence of hypopituitarism has been suggested with the use of SRS as compared with FSRT, although this is likely to reflect different patient selection. SRS is usually used to treat patients with smaller tumors than those treated with FSRT. Prospective studies comparing SRS with fractionated stereotactic radiotherapy in patients with pituitary adenomas similar in size would be of value to help define the long-term efficacy and toxicity of the techniques.

\section{Conclusion}

Radiation is highly effective in the management of patients with persistent active acromegaly after surgery and/or during medical therapy. Long-term data clearly indicate that conventional RT is able to achieve biochemical remission of disease in $50-60 \%$ of patients after 10 years, with an acceptable incidence of complications. Stereotactic techniques (SRS and FSRT) offer a more localized irradiation compared with conventional RT and have the potential of reducing the risk of long term radiation induced morbidity. Currently, SRS and FSRT represent common treatment modalities of irradiation for GH-secreting pituitary tumors, providing a comparable high rates of tumor control and endocrinological 
remission with low morbidity. The choice of the radiation technique should be based on tumor characteristics. In most centres SRS represent a convenient treatment for patients with relatively small residual adenomas not in close proximity of the optic chiasm, while FSRT is usually reserved to patients with larger $\mathrm{GH}$-secreting tumors not amenable to SRS. Efficacy and toxicity of hypofractionated treatment schedules need to be explored in future studies.

\section{Author details}

'Department of Neuroscience, Neuromed Institute, Pozzilli (IS), Italy. 2Department of Radiation Oncology, Sant' Andrea Hospital, University Sapienza, Rome, Italy.

\section{Authors' contributions}

GM and CS performed the database search, critically reviewed the existing data and drafted the manuscript. RME critically reviewed/revised the article. All authors read and approved the final manuscript.

\section{Competing interests}

The authors declare that they have no competing interests.

Received: 7 September 2011 Accepted: 2 December 2011

Published: 2 December 2011

\section{References}

1. Colao A, Ferone D, Marzullo P, Lombardi G: Systemic complications of acromegaly: epidemiology, pathogenesis, and management. Endocr Rev 2004, 25:102-152.

2. Minniti G, Jaffrain-Rea ML, Esposito V, Santoro A, Tamburrano G, Cantore G: Evolving criteria for post-operative biochemical remission of acromegaly: can we achieve a definitive cure? An audit of surgical results on a large series and a review of the literature. Endocr Relat Cancer 2003, 10:611-619.

3. Minniti G, Moroni C, Jaffrain-Rea ML, Esposito V, Santoro A, Affricano C, Cantore G, Tamburrano G, Cassone R: Marked improvement in cardiovascular function after successful transsphenoidal surgery in acromegalic patients. Clin Endocrinol(Oxf) 2001, 55:307-313.

4. Jaffrain-Rea ML, Minniti G, Moroni C, Esposito V, Ferretti E, Santoro A, Infusino T, Tamburrano G, Cantore G, Cassone R: Impact of successfu transsphenoidal surgery on cardiovascular risk factors in acromegaly. Eur J Endocrinol 2003, 148:193-201.

5. Melmed S: Medical progress: Acromegaly. N Engl J Med 2006, 355:2558-2573.

6. Minniti G, Gilbert DC, Brada M: Modern techniques for pituitary radiotherapy. Rev Endocr Metab Disord 2009, 10:135-144.

7. Brada M, Ajithkumar TV, Minniti G: Radiosurgery for pituitary adenomas. Clin Endocrinol (Oxf) 2004, 61:531-543.

8. Barkan AL, Halasz I, Dornfeld KJ, Jaffe CA, Friberg RD, Chandler WF, Sandler HM: Pituitary irradiation is ineffective in normalizing plasma insulin-like growth factor I in patients with acromegaly. J Clin Endocrinol Metab 1997, 82:3187-3191.

9. Thalassinos NC, Tsagarakis S, loannides G, Tzavara I, Papavasiliou C: Megavoltage pituitary irradiation lowers but seldom leads to safe $\mathrm{GH}$ levels in acromegaly: a long-term follow-up study. Eur J Endocrinol 1998, 138:160-163.

10. Barrande G, Pittino-Lungo M, Coste J, Ponvert D, Bertagna X, Luton JP, Bertherat $\mathrm{J}$ : Hormonal and metabolic effects of radiotherapy in acromegaly: long-term results in 128 patients followed in a single center. J Clin Endocrinol Metab 2000, 85:3779-3785.

11. Biermasz NR, van Dulken H, Roelfsema F: Long-term follow-up results of postoperative radiotherapy in 36 patients with acromegaly. J Clin Endocrinol Metab 2000, 85:2476-2482.

12. Cozzi R, Barausse M, Asnaghi D, Dallabonzana D, Lodrini S, Attanasio R: Failure of radiotherapy in acromegaly. Eur J Endocrinol 2001, 145:717-726

13. Epaminonda P, Porretti S, Cappiello V, Beck-Peccoz P, Faglia G, Arosio M: Efficacy of radiotherapy in normalizing serum IGF-I, acid-labile subunit
(ALS) and IGFBP-3 levels in acromegaly. Clin Endocrinol (OXf) 2001, 55:183-189.

14. Minniti G, Jaffrain-Rea ML, Osti M, Esposito V, Santoro A, Solda F, Gargiulo P, Tamburrano G, Enrici RM: The long-term efficacy of conventional radiotherapy in patients with GH-secreting pituitary adenomas. Clin Endocrinol (Oxf) 2005, 62:210-216.

15. Jenkins PJ, Bates P, Carson MN, Stewart PM, Wass JA: Conventional pituitary irradiation is effective in lowering serum growth hormone and insulin-like growth factor-I in patients with acromegaly. J Clin Endocrinol Metab 2006, 91:1239-1245.

16. Giustina A, Chanson P, Bronstein MD, Klibanski A, Lamberts S, Casanueva FF, Trainer P, Ghigo E, Ho K, Melmed S: Acromegaly Consensus Group. A consensus on criteria for cure of acromegaly. J Clin Endocrinol Metab 2010, 95:3141-3148.

17. Brada M, Ashley S, Ford D, Traish D, Burchell L, Rajan B: Cerebrovascular mortality in patients with pituitary adenoma. Clin Endocrinol (Oxf) 2002, 57:713-717.

18. Erfurth EM, Bülow B, Svahn-Tapper G, Norrving B, Odh K, Mikoczy Z, Björk J, Hagmar L: Risk factors for cerebrovascular deaths in patients operated and irradiated for pituitary tumors. J Clin Endocrinol Metab 2002, 87:4892-4899.

19. Tsang RW, Laperriere NJ, Simpson WJ, Brierley J, Panzarella T, Smyth HS: Glioma arising after radiation therapy for pituitary adenoma. A report of four patients and estimation of risk. Cancer 1993, 72:2227-2233.

20. Minniti G, Traish D, Ashley S, Gonsalves A, Brada M: Risk of second brain tumor after conservative surgery and radiotherapy for pituitary adenoma: update after an additional 10 years. J Clin Endocrinol Metab 2005, 90:800-804.

21. Douw L, Klein M, Fagel SS, van den Heuvel J, Taphoorn MJ, Aaronson NK Postma TJ, Vandertop WP, Mooij JJ, Boerman RH, Beute GN, Sluimer JD, Slotman BJ, Reijneveld JC, Heimans JJ: Cognitive and radiological effects of radiotherapy in patients with low-grade glioma: long-term follow-up. Lancet Neurol 2009, 8:810-818.

22. Peace KA, Orme SM, Thompson AR, Padayatty S, Ellis AW, Belchetz PE: Cognitive dysfunction in patients treated for pituitary tumours. J Clin Exp Neuropsychol 1997, 19:1-6.

23. Noad R, Narayanan KR, Howlett T, Lincoln NB, Page RC: Evaluation of the effect of radiotherapy for pituitary tumours on cognitive function and quality of life. Clin Oncol (R Coll Radiol) 2004, 16:233-237.

24. Tooze A, Gittoes NJ, Jones CA, Toogood AA: Neurocognitive consequences of surgery and radiotherapy for tumours of the pituitary. Clin Endocrinol (Oxf) 2009, 70:503-511.

25. Minniti G, Valeriani M, Clarke E, D'Arienzo M, Ciotti M, Montagnoli R, Saporetti F, Enrici RM: Fractionated stereotactic radiotherapy for skull base tumors: analysis of treatment accuracy using a stereotactic mask fixation system. Radiat Oncol 2010, 5:1.

26. Milker-Zabel S, Zabel A, Huber P, Schlegel W, Wannenmacher M, Debus J: Stereotactic conformal radiotherapy in patients with growth hormonesecreting pituitary adenoma. Int I Radiat Oncol Biol Phys 2004, 59:1088-1096

27. Colin P, Jovenin N, Delemer B, Caron J, Grulet H, Hecart AC, Lukas C, Bazin A, Bernard MH, Scherpereel B, Peruzzi P, Nakib I, Redon C, Rousseaux P: Treatment of pituitary adenomas by fractionated stereotactic radiotherapy: a prospective study of 110 patients. Int $J$ Radiat Oncol Biol Phys 2005, 62:333-341.

28. Minniti G, Traish D, Ashley S, Gonsalves A, Brada M: Fractionated stereotactic conformal radiotherapy for secreting and nonsecreting pituitary adenomas. Clin Endocrinol (Oxf) 2006, 64:542-548.

29. Roug S, Rasmussen AK, Juhler M, Kosteljanetz M, Poulsgaard L, Heebøll H, Roed $\mathrm{H}$, Feldt-Rasmussen U: Fractionated stereotactic radiotherapy in patients with acromegaly: an interim single-centre audit. Eur J Endocrinol 2010, 162:685-694.

30. Mackley HB, Reddy CA, Lee SY, Harnisch GA, Mayberg MR, Hamrahian AH, Suh $\mathrm{JH}$ : Intensity-modulated radiotherapy for pituitary adenomas: the preliminary report of the Cleveland Clinic experience. Int J Radiat Oncol Biol Phys 2007, 67:232-239.

31. Merchant TE: Proton beam therapy in pediatric oncology. Cancer J 2009, 15:298-305.

32. Petit JH, Biller BM, Coen JJ, Swearingen B, Ancukiewicz M, Bussiere M, Chapman P, Klibanski A, Loeffler JS: Proton stereotactic radiosurgery in management of persistent acromegaly. Endocr Pract 2007, 13:726-734. 
33. Ronson BB, Schulte RW, Han KP, Loredo LN, Slater JM, Slater JD: Fractionated proton beam irradiation of pituitary adenomas. Int J Radiat Oncol Biol Phys 2006, 64:425-434.

34. Attanasio R, Epaminonda P, Motti E, Giugni E, Ventrella L, Cozzi R, Farabola M, Loli P, Beck-Peccoz P, Arosio M: Gamma-knife radiosurgery in acromegaly: a 4-year follow-up study. J Clin Endocrinol Metab 2003, 88:3105-3112.

35. Jane JA Jr, Vance ML, Woodburn CJ, Laws ER Jr: Stereotactic radiosurgery for hypersecreting pituitary tumors: part of a multimodality approach. Neurosurg Focus 2003, 14:e12.

36. Castinetti F, Taieb D, Kuhn JM, Chanson P, Tamura M, Jaquet P, ConteDevolx B, Régis J, Dufour H, Brue T: Outcome of gamma knife radiosurgery in 82 patients with acromegaly: correlation with initial hypersecretion. J Clin Endocrinol Metab 2005, 90:4483-4488.

37. Gutt B, Wowra B, Alexandrov R, Uhl E, Schaaf L, Stalla GK, Schopohl J: Gamma-knife surgery is effective in normalising plasma insulin-like growth factor I in patients with acromegaly. Exp Clin Endocrinol Diabetes 2005, 113:219-224.

38. Kobayashi T, Mori Y, Uchiyama Y, Kida Y, Fujitani S: Long-term results of gamma knife surgery for growth hormone-producing pituitary adenoma: is the disease difficult to cure? J Neurosurg 2005, 102(Suppl):119-123.

39. Jezková J, Marek J, Hána V, Krsek M, Weiss V, Vladyka V, Lisák R, Vymazal J, Pecen L: Gamma knife radiosurgery for acromegaly-long-term experience. Clin Endocrinol (Oxf) 2006, 64:588-595.

40. Voges J, Kocher M, Runge M, Poggenborg J, Lehrke R, Lenartz D, Maarouf M, Gouni-Berthold I, Krone W, Muller RP, Sturm V: Linear accelerator radiosurgery for pituitary macroadenomas: a 7-year followup study. Cancer 2006, 107:1355-1364.

41. Pollock BE, Jacob JT, Brown PD, Nippoldt TB: Radiosurgery of growth hormone-producing pituitary adenomas: factors associated with biochemical remission. J Neurosurg 2007, 106:833-838.

42. Vik-Mo EO, Oksnes M, Pedersen PH, Wentzel-Larsen T, Rødahl E, Thorsen F, Schreiner T, Aanderud S, Lund-Johansen M: Gamma knife stereotactic radiosurgery for acromegaly. Eur J Endocrinol 2007, 157:255-263.

43. Jagannathan J, Sheehan JP, Pouratian N, Laws ER Jr, Steiner L, Vance ML: Gamma knife radiosurgery for acromegaly: outcomes after failed transsphenoidal surgery. Neurosurgery 2008, 62:1262-1269.

44. Losa M, Gioia L, Picozzi P, Franzin A, Valle M, Giovanelli M, Mortini P: The role of stereotactic radiotherapy in patients with growth hormonesecreting pituitary adenoma. J Clin Endocrinol Metab 2008, 93:2546-2552.

45. Ronchi CL, Attanasio R, Verrua E, Cozzi R, Ferrante E, Loli P, Montefusco L, Motti E, Ferrari Dl, Giugni E, Beck-Peccoz P, Arosio M: Efficacy and tolerability of gamma knife radiosurgery in acromegaly: a 10-year follow-up study. Clin Endocrinol (Oxf) 2009, 71:846-852.

46. Wan H, Chihiro O, Yuan S: MASEP gamma knife radiosurgery for secretory pituitary adenomas: experience in 347 consecutive cases. J Exp Clin Cancer Res 2009, 28:36.

47. Hayashi M, Chernov M, Tamura N, Nagai M, Yomo S, Ochiai T, Amano K, Izawa M, Hori T, Muragaki Y, Iseki H, Okada Y, Takakura K: Gamma Knife robotic microradiosurgery of pituitary adenomas invading the cavernous sinus: treatment concept and results in 89 cases. J Neurooncol 2010, 98:185-194.

48. Iwai Y, Yamanaka K, Yoshimura M, Kawasaki I, Yamagami K, Yoshioka K: Gamma knife radiosurgery for growth hormone-producing adenomas. J Clin Neurosci 2010, 17:299-304.

49. Landolt AM, Haller D, Lomax N, Scheib S, Schubiger O, Siegfried J, Wellis G: Stereotactic radiosurgery for recurrent surgically treated acromegaly: comparison with fractionated radiotherapy. J Neurosurg 1998, 88:1002-1008.

50. Loeffler JS, Niemierko A, Chapman PH: Second tumors after radiosurgery: tip of the iceberg or a bump in the road? Neurosurgery 2003, 52:1436-1440.

51. Adler JR Jr, Gibbs IC, Puataweepong P, Chang SD: Visual field preservation after multisession cyberknife radiosurgery for perioptic lesions. Neurosurgery 2006, 59:244-254.

52. Kajiwara K, Saito K, Yoshikawa K, Kato S, Akimura T, Nomura S, Ishihara H, Suzuki M: Image-guided stereotactic radiosurgery with the CyberKnife for pituitary adenomas. Minim Invasive Neurosurg 2005, 48:91-96.

53. Roberts BK, Ouyang DL, Lad SP, Chang SD, Harsh GR, Adler JR Jr, Soltys SG, Gibbs IC, Remedios L, Katznelson L: Efficacy and safety of CyberKnife radiosurgery for acromegaly. Pituitary 2007, 10:19-25.
54. Morange-Ramos I, Regis J, Dufour H, Andrieu JM, Grisoli F, Jaquet $P$, Peragut JC: Gamma-knife surgery for secreting pituitary adenomas. Acta Neurochir (Wien) 1998, 140:437-443.

doi:10.1186/1748-717X-6-167

Cite this article as: Minniti et al:: Radiation techniques for acromegaly. Radiation Oncology 2011 6:167.

\section{Submit your next manuscript to BioMed Central and take full advantage of:}

- Convenient online submission

- Thorough peer review

- No space constraints or color figure charges

- Immediate publication on acceptance

- Inclusion in PubMed, CAS, Scopus and Google Scholar

- Research which is freely available for redistribution

Submit your manuscript at www.biomedcentral.com/submit
Biomed Central 